\title{
Öykü Çözümlemelerinde Sinema Dili ve Anlatım Teknikleri BİRSEL SAĞIROĞLU*
}

Öz

Edebiyatın temel malzemesi sözcüklerdir ve edebiyatta anlam dil göstergeleri yoluyla yaratılır. Sinema ise kendi yasaların "hareketli görüntü"lerle ortaya koymaktadır. Bu hareketli görüntüler -edebiyatta olduğu gibi- kuramcılar tarafından yeni anlatım olanaklarıyla desteklenir. Bu çalışmada, Eisenstein'ın diyalektik öğreti ilkesine dayalı "kurgu teknikleri"yle birlikte sinemadaki "genel kurgu teknikleri" ve "kamera çekim yasaları" göz önünde bulundurularak Sevim Burak'ın "Pencere", Necati Cumalı'nın "Akhisarlı" ve Sevgi Soysal'ın "Bir Şeydi Hiçliği Hiç Olup Yitti” adlı öyküleri, ilkin film senaryosuna dönüştürülmüss ardından öykülerde bu kurgu tekniklerinin izleri sürülmüştür. Eisenstein'ın görüntü yardımıyla ulaşmaya çalıştığı diyalektik öğreti, öyküde sözcüklerden hareketle ifade edilmeye çalı̧̧lmıştır. Böylece öykü evreni, yeni uygulama olanaklarıyla ve terminolojiyle buluşturularak özgün bir biçimci edebiyat dili oluşturulmuştur.

Anahtar sözcükler: Öykü, Diyalektik Öğreti, Biçimci Sinema, Kurgu.

\section{CINEMA LANGUAGE AND NARRATIVE TECHNIQUES \\ IN STORY ANALYSIS}

\section{Abstract}

Basic material of literature is words and meaning in literature is created with linguistic signs. Cinema expresses its laws with moving images. As in literature, these images are supported with new explanation possibilities by theorists. In this study, the stories called "Pencere" by Sevim Burak, "Akhisarlı" by Necati Cumalı and "Bir Şeydi Hiçliği Hiç Olup Gitti" by Sevgi Sosyal was firstly turned into film script and tracked the fiction techniques in stories by considering general fiction techniques, shotting laws in cinema and fiction techniques based on Eisenstein's dialectic principles. Dialectic principle, which Eisenstein tried to reach with the help of image, was tried to be explained with words in story. Hence, an authentic formalist literary language was constructed by bringing story universe together with new practice possibilities and terminology.

Keywords: Story, Dialectic Principle, Formalist Cinema, Fiction.

\footnotetext{
*Eskişehir Osmangazi Üniversitesi Sosyal Bilimler Enstitüsü doktora programı, birselsagiroglu@gmail.com
} 


\section{Giriş}

inema ve edebiyat etkileşiminin uzun yıllara dayandığı bilinir. Teknolojik gelişmelerle kendini yenileyen sinemanın fotoğraf, müzik, resim, edebiyat, tiyatro gibi birçok sanattan yararlandığı ve böylece kendi özgül yasalarını oluşturduğu dikkat çeker. Rita Felski'ye göre “İster kurmaca, ister olgusal, ister şiirsel, ister retorik olsun, bu türlerin her biri bir dizi şema yaratır, dili belli ölçütlere göre seçer, düzenler ve şekillendirir, bazı görme biçimlerine kapı aralarken bazılarını dışarıda bırakır." (2010: 129). Ancak genç bir sanat olan sinema, birçok sanattan beslenirken farkını görüntülerle ortaya koymaktadır. Gerçeklikten esinlenilerek oluşturulan bu görüntüler farklı amaçlarla yan yana getirilir. Sözgelimi, dışavurumcu sinemada 1şık, renk, uzam gibi ögelerin imge değeri ön plana çıkarılırken biçimci sinemada filmin biçimine ait unsurlar gözetilir, post yapısalcı sinema ise eserde gerçeğin ne olduğuna dair düşünceyi irdelemektedir. Dolayısıyla edebiyatta olduğu gibi sinemada da sabit bir dilden söz edilemez.

Sinemanın ortaya çıkışıyla birlikte sinemanın bir sanat olarak değerlendirilemeyeceği, endüstriyel bir oluşum olduğu ve ticari kaygılarla ortaya çıktığı yolunda pek çok fikir öne sürülür. Sergei Eisenstein gibi kuramcilar onun sanat olması amacıyla hareket eder ve sinemanın kuramsal boyutuna katkıda bulunurlar. Deneyler yapan düşünür olarak bilinen Eisenstein (1898-1948), biçimci sinemayı çarpışan çekim parçalarını dolayısıyla da "sanatsal kurgu"yu kullanarak destekler. Onun deyimiyle kurgu “öylesine güçlüdür ki sinemanın bütün anlatım gücünü kendi çıkarına silip süpürür" (Eisenstein 1985: 140). Eisenstein'ın kurgu kuramının temelinde ise diyalektik öğretisi vardır. Buna göre bir olayın özü tezantitez çatışmasından doğar. 0, sanatın çatışma ile doğanın kesiştiği yerde aranması gerektiğine inanır. Böylece ikisinin karşılıklı etkileşimi sadece zaman ve mekân sürekliliğinde değil, düşünce alanında da dinamizmi oluşturur (1985: 57-58).

Diyalektik yasalarında özel bir şeyden yola çıkılarak genel olana doğru gidilir, özel ve genel olan bir bütün olarak kavranır. Bir şeyin özünde ne olduğu onun ilişkide bulunduğu diğer şeyler tarafından belirlenir (Ryan 2012: 88). Eisenstein'ın filmlerinde de kaba gerçeklik olduğu gibi yansıtılmaz, değişime uğratılır ve sinemada şiirsel bir dil kullanılır. İzleyicide duygusal bir etki yaratabilmek amacıyla perdede çelişik veya zıt görüntülerden yararlanılır. Kurgu kuramını laboratuvar ortamında geliştiren Eisenstein; çarpıcı, ölçümlü, üsttitremsel, dizemsel, titremsel, anlıksal, çağrısımsal olmak üzere yedi tane kurgu tekniği yaratır.

Eisenstein, izleyicide duygusal bir etki yaratabilmek amacıyla perdede çelişik veya zıt görüntülerden yararlanır ve onun kurgu teknikleri birbirinin devamı niteliğindedir. Örneğin, ölçümlü kurguda kurguyu oluşturan temel öge çekimlerin uzunluğudur. Bu çekim uzunluğu, çekimin iç hareketiyle çatıştığında dizemsel kurgu ortaya çıkmaktadır. Çekimdeki dizemsel ilkeler titremsel ilkelerle çatışırsa da titremsel kurgu oluşmakta temel ögeyle 
üsttitrem arasındaki çatışmadan üsttitremsel kurgu; üsttitremsel kurgu ile ideolojik niteliklerin çatışmasıyla anlıksal kurgu türetilir (Eisenstein 1984: CXL). Bu kurgu teknikleri dışında çekim içinde yer alan çeşitli çizgilerin, doğruların birbirleriyle çatışmasında "çizemsel çatışma”, varlıkların boyutlarından kaynaklanan "oylumsal çatışma", uzam parçalarının çatışmasıyla "uzamsal çatışma", 1şık derecelerinin (karanlık, aydınlık, loşluk) çatışmasıyla "1şık çatışması" ve bir yanda optik diğer yanda akustik alanlar arasındaki çatışma "görsel ve işitsel alanlar arasındaki çatışma" olarak adlandırılır (Eisenstein 1984: (XV).

Öykü çözümlemelerinde

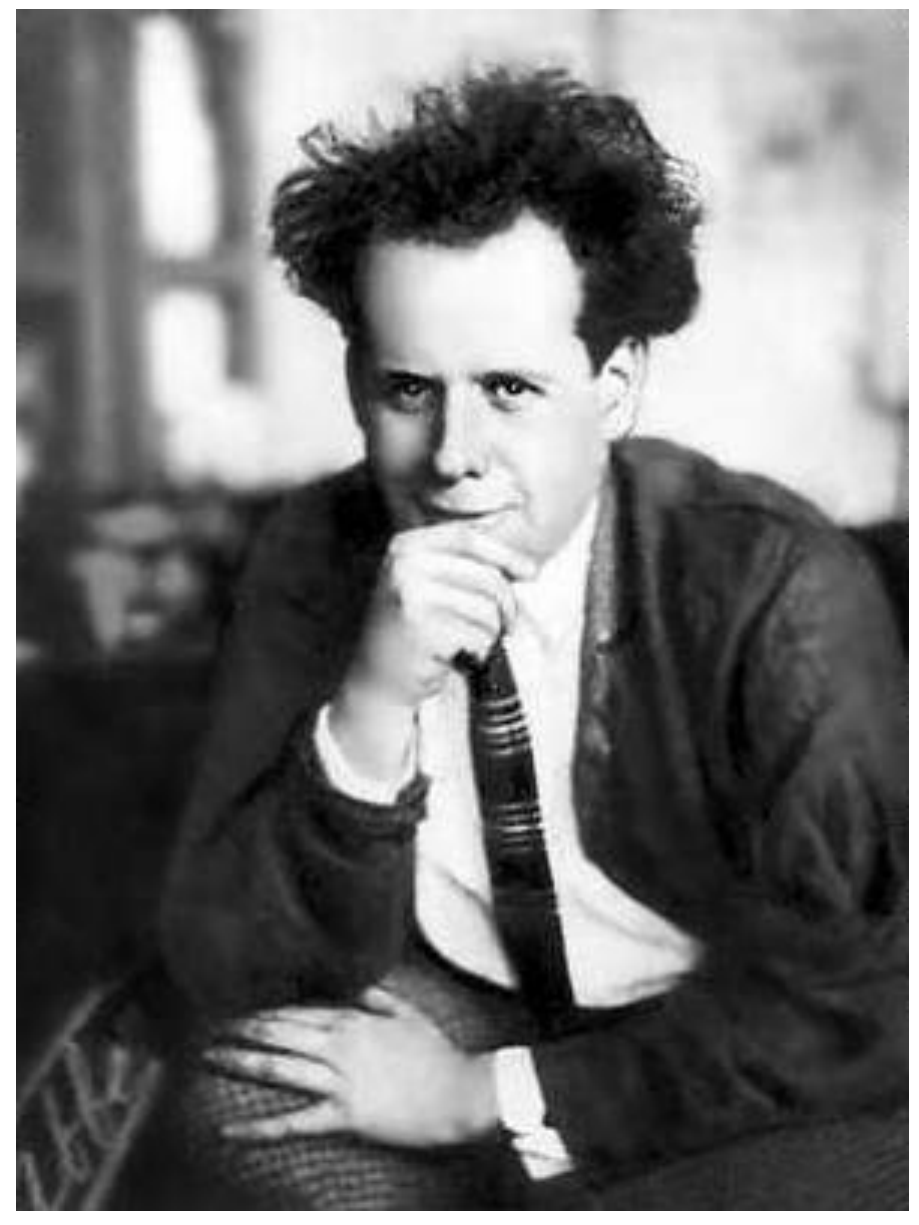

Sergey Ayzeştayn

yararlanılan diğer kaynak "genel kurgu

teknikleri"dir. Filmin içeriği doğrultusunda oluşturulan bu tekniklerle bir filmin zamandizinselliği, betimleyici veya anlatıma dayalı olmasıyla ilgili bazı ögeler ön plana çıkarılır. Şöyle ki bir filmde duygusal unsurlar ağır basıyorsa "patetik kurgu", zamanda eksiltme yapılmışsa "olağan kurgu" ya da birbirine zıt çekimler art arda sıralanıyorsa "karşıt kurgu" adı verilen teknikler ortaya çıkar. Genel kurgu teknikleri "hızlı-yavaş kurgu”, "karşıt kurgu”, "koşut kurgu”, “olağan kurgu”, "bağıntılı kurgu”, “eliptik kurgu”, “düz kurgu”, "dışavurumcu kurgu"," metaforik kurgu", "patetik kurgu" olarak sinıflandırılabilir.

Kamera çekim tekniklerinde ise ölçüt insan ya da herhangi bir nesnedir. Dolayısıyla bu teknikler "insan"ın veya nesnenin görüntüdeki konumuna göre adlandırılır. Örneğin, yakın çekim, bir insanın göğüs ve omuz hizasından görüntüsü veya o alana sığabilecek diğer obje ve görüntülerdir. Görüntü yakın plan sayesinde ilgi çekici hâle gelir ve bu teknikle görüntü görsel biçiminden saparak, görüntünün içeriği değişir. Yakın planda görüntü, gerçekte algılandığından farklı algılanır ve farklı çağrışımlar yaratır (Küçükerdoğan 2010: 117). "Genel çekim", “omuz çekim”, "üst açı" gibi kavramlar ise kamera konumuyla ilgilidir. Yakın planla sıkışık bir çerçeve oluşturulurken bir genel planla -kameranın eylemden uzak olma durumu- rahat bir çerçeve meydana gelmektedir (Ryan 2012: 178). Diğer çekim planları 
kısaca şöyle tanımlanabilir: Bir kişinin bel hizasından görüntüsü veya o alana sığabilecek diğer obje ve görüntülere "orta (omuz) çekim"; bir insan boyunun çerçeveye sığdırılması veya aynı ölçekteki çerçeveye sığan diğer obje ve görüntülerin toplamına "boy çekim"; kim olduğu belli olmayacak kadar uzaktan görünen insan ve diğer objelerin yer aldığı çekime "uzak çekim" denilirken genel planın mizansende derinlik oluşturacak şekilde biraz daha uzaktan görüntüsüne de "uzak perspektif" denmektedir. Görüntü, kameranın kendi etrafında sağa sola çevrilme hareketiyle elde edildiğinde ise "panoramik çekim" ortaya çıkmakta, kameranın düz ayak ya da vinç üzerinde yukarı aşağı kaydırma hareketine de "tild" denmektedir. Bunlar dışında zum, karşı açı çekim, görüntünün sonlandırılması anlamına gelen "kesme tekniği" gibi pek çok teknik bu grupta ele alınabilir.

Çalışmada, bu teknikler yol gösterici olmuş ancak sinemada görüntü diliyle elde edilen teknikler öykülerde sözcüklerden hareketle ifade edilmeye çalışılmıştır. Dolayısıyla da sözcükler yardımıyla öyküler hareketli görüntülere dönüştürülmüş ve sinemaya ait terminoloji bu görüntülere uyarlanmıştır.

\section{Sinema Diliyle Öykü Çözümlemeleri}

\section{1. "Pencere"}

Çözümlemede amaç, öyküleri sinema diline dönüştürmek ve sinemaya özgü kavramları bu öykülerde gösterebilmektir. Öyküler film senaryosuna dönüştürüldüğü için ilkin "sahne" terimini tanımlamak faydalı olacaktır. Sahne, bir filmdeki olaylar dizisi olarak bilinir ve sahnenin en belirgin özelliği çizgisel anlatıma dayalı olmasıdır. Sevim Burak’ın bu öyküsü, kahramanı kadın olan karakterin bakış açısını yansıtmaktadır. Bundan dolayı kadının gözleri kamera görevi görür ve öykünün sahneleri şöyle sıralanabilir:

1. Karşı apartmandaki kadının tasviri

2. Kadın kahramanın ruh hâli

3. Dış dünya ve kadının iç dünyasının tanımlanması

4. Kadının kurmaca dünyası

5. Kadının yalnızlı̆̆ ve hayalleri

6. Kadının intihar etmesi

\subsection{Dramatik Çatışma}

Öykünün çekim tekniklerine geçmeden önce öykünün tamamında yer alan "dramatik çatışma"dan bahsedilecektir. Semir Aslanyürek'e göre yaşamın çelişkilerini dile getirmenin kendine özgü estetik bir biçimi veya insanların birbirine zıt olan davranışlarının, fikirlerinin sanatta canlandırılması sonucu ortaya çıkan terim "dramatik anlaşmazlık"tır. Betimsel düşünmenin temeli kabul edilen dramatik anlaşmazlık, kahramanların kendi aralarında ya 
da bulundukları ortam veya doğal çevre arasındaki çelişkilerden ve bu çelişkilerin gelişmesinden doğar (2011: 94-95). "Pencere"de kadının iç dünyasındaki çatışmaların yaşamın gerçekleriyle uyuşmadığı dikkat çeker. Kadının düşüncelerinden doğan çatışmanın öykünün psikolojik yönünü açığa çıkardığı söylenebilir. Kadın karakter, öyküye yön verir, karakterin iç dünyasındaki çatışma da gerilim unsuru olarak dikkat çeker: "İkimiz de iyi değiliz. Kendini kaldırıp atmak için ufak bir işaretçik bekliyor benden; benim elimden çıkmış bir insanmışçasına istediklerimi yapıyor, buna karşılık onun ölümünü göreyim istiyor" (Burak 2014: 18). Bu ve buna benzer pek çok cümle öykünün tamamına yayılır ve kadının ruh durumunu somutlar. Kadın, insanın varoluşunu, ölümle ilgili tavrını ortaya koyar. Bu tavır da çatışmanın merkezi kabul edilebilir.

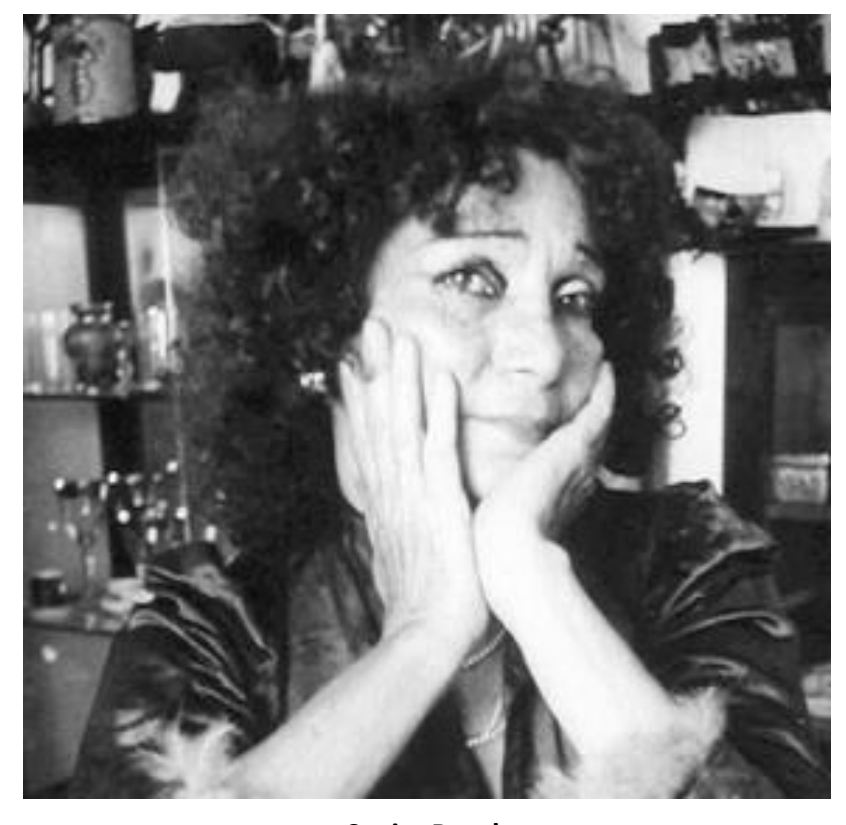

Sevim Burak

\subsection{Avangart Sinema}

Öykü farklı denebilecek bir yaklaşımla yazılmıştır. Gerçek ile rüyanın birleşmesi sonucu da öyküde anlatım olanaklarının zenginleştirildiğ $\mathrm{i}$ fark edilir. Nilgün Abisel'in dikkat çektiği üzere günün eleştirisini rüya ya da rüya benzeri görüntü düzenlemeleriyle filme taşıyan, zaman ve mekânın mantığını kırma yoluyla aktaran sinemacilar "avangart" kabul edilir (1989: 232). Avangartlık, sinemada yeni ve deneysel hareketi adlandırmak için kullanılır. Söz konusu

yeniliği bu öyküde görmek mümkündür. Hayali ve gerçek dünyanın iç içe geçtiği öyküde zamanda kırılmalar dikkat çeker. Öyküde görsel alan, yeni anlatım zenginliği yaratır. Karakterin ruhsal durumu, özgün bir dille yazılır. Mekandaki değişim veya zamandaki geçişler alışılmadık soyut bir dille aktarılır. Bu hızlı değişim öyküdeki zamandizinselliği bozar. Bu nedenle "avangart" kavramı bu öykünün genel havası için uygundur.

\section{Panoramik, Tild ve Diğer Çekim Teknikleri}

Öykü, kadının karşı apartmandaki kadını gözetlemesiyle başlar. Kamera karşı apartmandaki kadını görüntülediği için burada, bir kişinin bel hizasından görüntüsü veya o alana sığabilecek diğer obje ve görüntüleri kapsayan “omuz çekim”in kullanıldığ düşünülebilir. Sonrasında kesme yapılmadan kadının iç konuşmaları bu görüntüye eşlik eder: "Belki etmez, ne düşündüğünü bilmiyorum. Gizli kapaklı bir amacı olabilir" (Burak 
2014: 17). Bir pencereden öbürüne geçen kadın hareketi, sağlı sollu bir çekimle (panoramik) verilebilir. Burada görüntüler arası geçiş hızlıdır. Kadının adımları ile terasın yer aldığı sonraki çekimde ayrıntı plan dikkat çeker ve kadının her hareketinin yakından görüntüsü okurla buluşturulur: Çamaşırlar, duvardaki ipler ve kadının iç konuşması. Yarı beline kadar caddeye sarkan kadın ise "yakın perspektif"le arada derinlik oluşturacak ve başka objeler bulunmayacak şekilde yakından görüntülenir. Görüntüye yine kadının iç konuşmaları eşlik eder (Burak 2014: 17).

İkinci sahnede kamera ev içine kayar "kırmızı güllü perde ve perdede açılan küçük bir delik" ayrıntı çekimle verildikten sonra görüntü tekrar kadına, kadının sargılı ayağına kayar ve ayrıntı çekim tildle devam ettirilir. Bu görüntüden sonra gerçek dünya yerini, kadının fantastik dünyasına bırakır. Fantastik dünyada, ayağı sargılı kadının balkondan düşüşü, aşağı çekimle verildikten sonra al renkli ayağın görüntüsünde "yakın perspektif"ten yararlanılır. Fakat “caddeden gelip geçenler ya da caddeye taşan kan" görüntüsünde uzak çekim kullanılır. Bu uzak çekime tekrar iç konuşmalar eşlik eder: "sihirli bir iki saniyede cesedin kutsallaşıp büyüdüğünü -her şeyin değişip mutlu sona bağlandığını- düşünüyorum" (Burak 2014: 18). Bu iç konuşmalardan sonra gerçek dünyadan bir ayrıntı çekim verilir: kadının gülümsemesi.

\subsection{Peripeti}

Aristo'ya göre tragedyaların en önemli araçlarından biri peripeti yani baht dönüşleridir (2012: 25). Peripeti, eylemlerin düşünülenin tam tersine dönmesidir. Sözgelimi, Oidipus'ta bir çoban, sevindirici bir haber vermek için Oidipus'a gelir. Fakat Oidipus'un geçmişini örten örtüyü kaldırmakla da düşündügünün tam tersini yapar (2012: 34). Aslanyürek'e göre de bir olayı daha ilginç ve karmaşık hâle getiren değişiklik veya karşı olay "peripeti"dir. Peripeti, olayların akışında veya kahramanların yazgısında beklenmeyen ani dönüşler veya değişikliklerdir (2011: 99). “Pencere”de kadının dünyası, peripeti tanımına uygundur. Çünkü onun iç dünyasındaki çatışma, karşı apartmandaki kadın aracılığıyla ilginç bir hâl alır. Örneğin, hayalî dünyadaki gülümsemenin ardından kadın cesedinin görüntüsü ayrıntı çekimle gösterilir. Daha sonra yerde yatan kadının kendi ölüsüne sevgi göstermesi ya da ölen kadının kolunu bacağını koparıp dostlarıyla konuşması, öyküde beklenmedik bir anda ve mekânda ortaya çıkar. Apartmandaki kadın, imge değeri yüksek bir anlatımın parçası olur ve öykü görsel zenginliğiyle ilginçleşir (Burak 2014: 18).

İkinci sahneden sonra görüntü kesilir. Kamera, yakın perspektif ve aşağ1 çekimle bomboş geçen otobüsleri çeker. Bu görüntüye yine hayalî çekimlerin sızdığı görülür. Kadın burada kendisini ve yaptıklarını anlatır: Bomboş geçen otobüslerin önüne attığı bir adam, koyun başlı bir kadın, keçi, inek, tilki başlı bir sürü insan başta uzak, sonrasında yakın çekim 
kullanılarak okura aktarılır. Sonraki çekimde kedi, tavşan, horoz gibi binlerce ayağın koşuşu aşağ 1 ve yakın çekimle verilir ve bu görüntü "kesme"ye uğrar. Kesmeden sonra ekranda yakın perspektifle beyaz sargılı bir bacak, bacaktaki pembe etler, birleşmemiş kemikler görünür. Bu görüntülerden sonra öyküde bir kesme daha yapılır, apartmandaki kadının terasta intihar edeceği duvara doğru yürümesi uzak çekimle verilirken kadının ayak hareketlerinde ayrıntı çekimden yararlanılır. Hayal şöyle devam eder: Terasın duvarında tek ayağının üstünde sallanan kadının genel çekimi; uzak çekimle sokağın başında görünen adamın koşarak kadına yetişmesi ve kadının kollarını açarak uçmak isteyişinin omuz çekimi; kadının sol gözünün ayrıntı çekimi gösterilir ( Burak 2014: 20).

Beşinci sahnede kadın, "HIÇBİR ŞEYDEN UMUDUM YOKTU. DENEMIŞTIM HER ŞEYİ KENDİ HESABIMA" (Burak 2014: 21) cümleleriyle iç dünyasını okurla paylaşır ve fantastik dünya kaybolur. Kamera burada ayrıntı çekimle perdenin ucunu gösterir ve aşağı kayar. Koltuğun arkasına sıkıştırılmaya çalışılan perde görüntüsüyle ayrıntı çekim devam eder. Görüntülerle ilerleyen tek şey kadının iç konuşmalarıdır. Daha sonraki çekimde, bir anı defterine çizilen ve karalanan bir evin, bir caddenin, bir bulutun, yeşil şapkalı bir adamın ayrıntı çekimi vardır. Ayrıca kadın bu sahneden sonra fantastik dünyasını okura şöyle anlatır: "Bir başıma her zaman böyle bir oyun oynayıp bozabileceğimi, Yeşil Şapkalı Adam'ın da bu oyunu oynayabileceğini, karşıdaki kadının, başka başka insanların da başka başka oyunlar oynayıp bozabileceklerini düşünüyorum" ( Burak 2014: 22).

Son sahnede, gerçek ve hayal yine bir aradadır. Sahne, apartmandaki kadının gözlerinin ayrıntı çekimi ile başlar ve hayal bu görüntüyle son bulur. Yeni görüntüde kararan havanın genel çekimi, perdedeki ölüm çiçekleri ile evin içindeki dolap, yatak, saç firketelerinin yakın perspektifi yer alır. Bu nesneler arasında geçiş hızlıdır. Sahnenin sonunda da kadın, uzak çekimle caddeyi, caddedeki kalabalığı; yakın perspektifle yeşil şapkalı adamı ve onun şapkasını ön plana çıkarır: "Şapkasını çıkarıp sallıyor. 'Sen de gelsene,' diyor" (Burak 2014: 23). Kamera son çekimde, yarı beline kadar sarkan kadının gürültüyle düşmesini yakın ve aşağı çekimle gösterir.

\subsection{Koşut Kurgu}

Genel kurgu teknikleri göz önünde bulundurulduğunda "koşut kurgu"nun bu öyküde yer aldığı söylenebilir. Koşut kurgu, merkezde yer alan bir olayın etrafında gelişen yan olaylarla bağlantısının çekim sırasıyla kurulmasıdır. Birbirinden uzak olaylar, imge yaratmak amacıyla art arda kullanılır. İki uzak gerçeklik, sırasıyla verilir ve filmin doruk noktasında bu olaylar buluşturulur (Asiltürk 2014: 143). “Pencere"de de gerçek dünya ile fantastik dünyaya ait görüntüler peş peşe verilir. Öykünün sonunda okur bu iki dünyayı birleştirebilir. Kadının ruh hâli imgesel değeri yüksek bir anlatımla aktarılır. Öykünün 
kurgusu, eylemlerin birbirine bir hareketin ortasından ötekine yapılan geçişlerle sağlanır. Örneğin, karşı apartmandaki kadının yarı beline kadar aşağı sarkması, kadının başını kaldırması, diğer kadının ona bakması ve perdenin arkasına geçmesi öyküye hareket kazandıran ögeler olarak değerlendirilebilir. Öykü gerçek dünyadan bir görüntüyle başlar, kadının iç dünyası bu görüntüye eklenir. Gerçek dünyadaki bir görüntünün ardından fantastik dünyada yere düşen kadının görüntüsü, caddeden gelip geçenler, kadının kendi ölüsüne gösterdiği sevgi, kadın kahramanın bomboş otobüslerin önüne tanıdık, tanımadık birilerini (bir adamı, koyun başlı kadını, keçi, tilki başlı bir sürü insan) itmesi dikkat çeker ve bütün ayakların kaçışmalarından sonra gerçek dünyadaki görüntüde, apartmandaki kadının terasta yürüyüşü gösterilir (Burak 2014: 17-19).

Bu görüntüden sonra yine fantastik dünyayı anlatan kadın, öykünün sonlarına doğru gerçek dünyayı kendi bakış açısıyla yorumlar. Görüntüde, perdenin arkasında umutsuzluğuyla yüzleşen anlatıcı konumundaki kadın, onun anı defterine çizdiği ve karaladığı resimde ev, cadde, adam, bulut, kararan hava ve kadının aşağı düşüşü vardır (Burak 2014: 21-23). Görüldüğü gibi iki ayrı dünyada farklı görüntülerin birbirini takip ettiği dikkat çekmektedir. Fantastik dünya, öykünün genel atmosferine uygun psikolojik ögelerden oluşmakta ve bu dünya koşut kurguda olduğu gibi imge yaratmak amacryla yaratılmaktadır. Öyküde kadının ruh hâli, gerçekliğin dışına çıkılarak sergilenir.

\section{5. Üsttitremsel Kurgu}

“Pencere"de, Eisenstein'ın kurgu tekniklerinden "üsttitremsel kurgu"nun kullanıldığ1 söylenebilir. Bu kurgu Peter Wollen'a göre çekimlerde ağır basan egemen ögeye göre yapılan titremsel kurguya karşılık olarak ortaya çıkarılmış ve Eisenstein tarafından "demokratik" kurgu olarak adlandırılmıştır. Bunun nedeni, üsttitremsel kurgunun yapılışında, titremsel kurgunun aksi bir durumun söz konusu olmasıdır. Bu kurguda, tek egemen ögeye bağımlı kalınması söz konusu değildir. Üsttitremsel kurgunun temel niteliği, yapılışı sırasında, bütün parçaların çekiciliklerinin dikkate alınıyor olmasıdır. Bu, titremsel kurgunun, egemen ögesinin ayrıcalığının sonunu getiren ve öteki uyaranların göz önüne alınmasını sağlayan bir durumdur ( 2014: 59). Bülent Küçükerdoğan ise bu kurguyu şöyle açıklar: “Gösteri ya da şölen olarak tanımlanan film, içindeki yüksek tonların toplamının ardından gelen parçalardaki yüksek tonlarla çatışma içerisinde bulunabileceği biçimde kurgulanmalıdır" (2010: 108). Bu kurguda film, müzik parçası gibi çok sayıda ton yaratır, bu tonların birbiriyle çarpışmasıyla yeni bir anlam oluşturulur.

Öyküde, iki farklı dünyadan görüntüler vardır. Özellikle hayalî dünyadaki görüntüler, tedirgin edicidir. Anlamsız eylemler (otobüsün önüne atılan insanlar), belirsizlikler (karşı apartmandaki kadın) art arda sıralanır. İki ayrı dünya öykünün iki tonunu temsil etmekte ve 
bu iki ton üsttitremsel kurguda olduğu gibi hem çatışmakta hem de birbirini beslemektedir. Böylece öyküde yeni anlamlar oluşmaktadır. Burada, tek egemen görüntünün olmadığ düşünülebilir. Bu nedenle öyküdeki bütün parçaların hemen hemen aynı seviyede çekiciliğe sahip olduğu söylenebilir.

\section{2. “Bir Şeydi Hiçliği Hiç Olup Yitti" \\ Sevgi Soysal'ın bu öyküsü beş ayrı bölümden oluşur. Her bölüm farklı bir sahne gibi düşünülebilir. Birbirinden bağımsız bu sahnelerde, öykü anlatıcısının izlenimleri okurla buluşturulur. Bundan dolayı çözümlemeye geçmeden önce izlenimcilik akımını tanıtmak uygun olacaktır.}

\section{1. İzlenimcilik}

Ufuk Güral'a göre bir sanat eserinde, gerçeğin tıpatıp

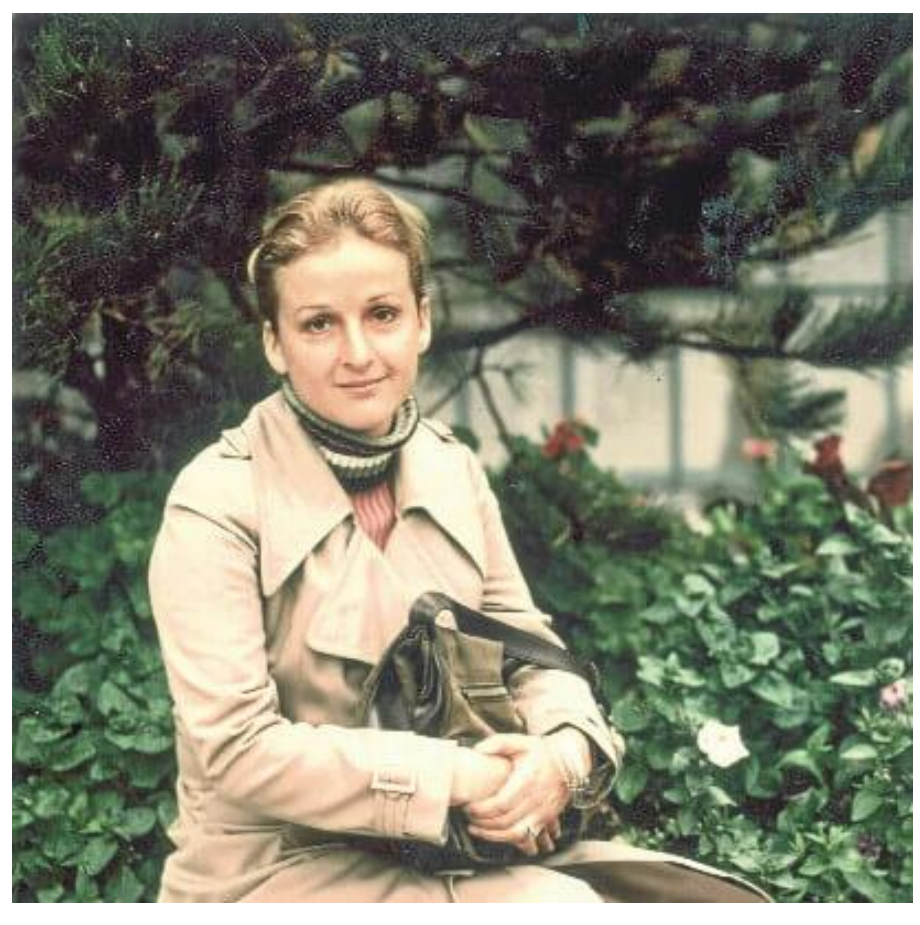

Sevgi Soysal aktarılması yerine sanatçının duyu âleminde yarattığı etkinin aktarılmasıyla "izlenimcilik (empresyonizm)" ortaya çıkar. Örneğin, bir resimde düzenli bir çizgi çalışmasından çok fırça darbeleri, düzensiz taramalar, karalamalar gibi unsurlar tuvale yansiyabilir (2013: 13). Bu akım sinemada, öyküden çok görselliğe yaslanır, sinemanın olanaklarından sonuna kadar yararlanilır.

Gerçeğin biçimbozumu olarak da adlandırılan "izlenimcilik"i bu öyküde tespit etmek mümkündür. "Tak, tak, tak, bir sincap sesi, bir çocuk ormanını süsledi. Tak, tak, tak makinenin sesi, bir erkek gerindi, esnedi. Sincap fındığını yedi. Bir kız çocuğu fındık gözlerini, ilk erkeğine gülümsetti" (Soysal 2012: 21) cümleleriyle anlatıcı, sözcüklerin gerçek anlamlarını aşan, imge gücü yüksek bir söyleyişle gerçekliğe yeni anlamlar kazandırır.

Öykünün her bölümü bir sahne gibi düşünüldüğünde her sahnede bu söyleyiş olanaklarının kullanıldığı söylenebilir. Ancak her sahne birbirinden bağımsız birden fazla ögenin olduğu karmaşık bir bütünden oluşur. Dolayısıyla bu öykünün yapısı gereği, çözümlemede sahneler belirlenmeyecektir, öykü bölüm bölüm incelenecektir. Buna göre ilk bölümde (sahne) demirler arasına gerilmiş ipler, iplere serilen çamaşırlar, çamaşırları yere seren fırtına genel çekimle aktarılır. Kameradaki kaydırmalarla öyküdeki görüntü hızla 
değişir. Havlayan bir köpek, fincanda içilen çaylar gibi ayrıntılarda yakın çekimden yararlanıldığı düşünülebilir (Soysal 2012: 21). Bu sahne birbirinden bağımsız unsurların kullanimiyla sonlanır.

İkinci bölümde, öyküdeki izlek tamamen değişir ve bu sahnenin önceki sahneyle arasında nedensellik bağ yoktur. Şöyle ki tavada ekşiyen yağların, biriken kirli, kokuşmuş çamaşırların ayrıntı çekimle verilen görüntüsünden sonra kamera bambaşka nesnelere ve eylemlere yönelir. Kamyonlara yüklenen buzdolaplarının, kamyonların, koltukların, halıların görüntüsünden sonra devrilen kamyonların görüntüsü gelir. Sahnenin sonunda ise eskiciler ve dilenciler eylemleriyle beraber anlatılır (Soysal 2012: 21). Bu görüntülerin ortak özelliği, kaydırmalardaki hızlı geçişlerdir. Kamera bir görüntüden diğerine seri şekilde geçer. Ancak kameranın yönü öykünün karmaşık yapısı nedeniyle belirsizdir. Sahnedeki kopuk parçalar birbirine iliştirilmiş bir görüntü ile okurun zihnini yorar.

\subsection{Renk ve Ses Ögeleri}

Öykünün son iki sahnesinde kaydırmalar olmakla birlikte nesneler ve eylemler arasında daha belirgin bir neden-sonuç ilişkisi dikkat çeker: Sabah karanlığında borazan sesi, kilitlenen kapılar, asfaltta çizme sesleri, sonra insan kemikleri, kan seli (Soysal 2012: 22). Görüldüğü üzere bu ögeler arasında ilişki daha açıktır. Burada, ses ve renk ögesi ön plandadır. Eisenstein'a göre renk ya da ses, yönetmenin gerekli gördüğü durumlarda bir coşkuyu daha etkili kılmak için kullanılan ve filmin amacına en doğru şekilde katkı sağlayacak unsurlardır (1984: 134-35). Ses, müzik ya da gürültü hem görüntüyü destekler hem de güçlendirir. Ancak bazen de ses görüntüleri desteklemek yerine karşı çıkar (Eisenstein 1984: CXLVII).

Sahnede, sabah karanlığında bir borazan sesi, somya gıcırtıları, rap ileri gibi söz gruplarında "ses"; karanlık, altın diş, kan seli kelimelerinde de "renk" ögesi olarak sahnenin anlatımını destekler. Kasvetli bir atmosferin rengi (sabahın karanlığı) "siyah"tır. Siyahlığın olumsuz anlamını pekiştiren bir başka renk "kırmızı"dır. Ayrıca sokaklardaki kan selinin renk olarak karşılığı kırmızıdır ve öyküde kırmızının ölümü ifade etmek amacıyla kullanıldığı düşünülebilir. Benzer şekilde bir borazanın sesi sabahın karanlı̆̆yla birleştiğinde gerilimi pekiştiren bir unsur olarak dikkat çeker. Dinen somya gıcırtıları ise dışarıdaki tedirgin edici atmosferin evdeki karşılığı olarak değerlendirilebilir. Sonraki görüntüde "rap, rap" sesleri, dış dünyadaki karanlığ 1 ve borazan seslerini anlam bakımından destekler. Bu sahnede renk ve ses ögesi çağrışım olanakları yüksek ögeler olarak sahnenin anlamını derinleştirerek öyküyü besler. Ayrı ayrı ögeler, nesneler dağınıklıklarına rağmen sahnenin bütününe katkı sağlayabilmiştir. Kamera hareketine de aynı dağınıklık hâkimdir. Görüntü genel çekimle başlar, sonrasında ayrıntı çekimle deri çizmeler ve somya 
görüntüsüne yer verilir. Mekânlar da hızla değişir. Kamera dışarıdayken ev içine kayar. Ev içi ayrıntı çekimle gösterilir: "Kapılar, pencereler kilitli". Tekrar dışarı kayan kamera, aşağı kayarak asfalttaki çizmeleri ve onların hareketini ayrıntı çekimle verir. Yığın yığın insan kemikleri, bir köşede altın dişler, resimler, evler (Soysal 2012: 22) gibi görüntüler, birbirini destekleyecek biçimde sıralanırken anlatıda görüntünün yönü sık sık değişir.

\section{3. Çarpıcı Kurgu}

Öyküde, "çarpıcı kurgu"nun etkisinden söz edilebilir. Eisenstein tarafından ortaya atılan bu kurgu, bir görüntünün anlamının bir başka görüntü ile yaklaştırılması, pekiştirilmesi olarak tanımlanır. Görüntülerin aynı olaya bağlı olması şart değildir. Çarpıcı kurguda hızlı-yavaş ya da kısa-yakın çekimlerin izleyiciyi etkilemesi beklenir. Çarpıcı kurgunun amacı, çağrışım uyandıran görüntü ile izleyicide tepki uyandırmaktır.

Öykünün tamamı düşünüldügünnde, ilk üç bölüm daha karmaşık ve öyküden kopuk gibi algılanır. Ancak her bölümde ayrıntı çekimlerle çağrışım gücü yüksek görüntülerin ortaya çıktığı söylenebilir. Son iki bölüm ise anlam bakımından daha açıktır. Öykünün bütün bölümlerinde göze çarpan şey "karamsar hava"dır. Her nesne, her eylem bu karamsarlığı destekler: İplerdeki çamaşırlar yere serilir, tavalarda yağlar ekşir, çamaşırlar kirlidir, kamyonlar devrilir ve pencereler kilitlidir. Ayrıca yığın yığın insan kemikleri, kan seli gibi pek çok söz grubu okuru etkileyebilecek niteliktedir. Bu görüntüler peş peşe dizildiğinde izleyicilerin kayıtsız kalamayacağı düşünülebilir. Dolayısıyla "çarpıcı kurgu", öykünün genel havasına uygun bir kavram olarak ön plana çıar. Ayrıca öyküden kopuk gibi görünen ilk üç bölümün, son iki bölümü yarattıkları olumsuz atmosferle destekleyen güçlü uyarıcılar konumunda oldukları da söylenebilir.

\section{4. Çizemsel, Oylumsal ve Görsel-İşitsel Alanlardaki Çatışma}

Öyküde, çekimler içinde yer alan çeşitli çizgilerin, doğruların birbiriyle zıtlaşması anlamına gelen "çizemsel çatışma"nın varlığından bahsedilebilir. Şöyle ki ilk bölümde demirlerin arasında gerili olan ipler ve iplerin üzerindeki beyaz çamaşırlar, rüzgârın etkisiyle yere serilir. Gerili ip veya ipin üzerindeki çamaşırlar, düz bir çizgi gibi düşünülebilir ancak yerdeki ip ve çamaşırlar görüntüsünde dağınıklık vardır. Bu iki görüntü çizemsel çatışmaya neden olur. Ayrıca, çekim içindeki varlıkların boyutlarının ortaya çıkardığı çatışma da (oylumların çatışması) üçüncü bölümde nettir: “Tak, tak, tak, bir sincap sesi, bir çocuk ormanını süsledi. Tak, tak, tak makinenin sesi, bir erkek gerindi" (Soysal 2012: 21) cümlelerinde bir çocuk ve bir erkek arasında varlıkların boyutlarından kaynaklanan çatışma dikkat çeker. Bir sincabın çıkardığı "tak, tak, tak" sesiyle makinenin çıkardığı aynı ses arasında da "görsel ve işitsel alanlardaki çatışma" dan söz edilebilir. 
Görsel ve işitsel alanlardaki çatışma, bir yanda optik diğer yanda akustik alanlar arasındaki çatışmadır. Film yönetmeni, çekimleri düzenlerken filmde bu türden çatışmalara yer vererek çatışmaları istediği şekilde yönetir (Eisenstein 1984: CXV). Bu iki sesten biri masumiyeti, diğeri şiddeti temsil eder. Bu da iki ses ve görüntü arasında çatışmaya neden olur.

\subsection{Metaforik Kurgu}

Birden fazla görüntü toplamının filmin simgesel gücü üzerine yapılandırılmasıyla ortaya çıkan "metaforik kurgu"nun bu öykünün yapısına uygun olduğu söylenebilir. "Bir Şeydi Hiçliği Hiç Olup Yitti", anlatımı bakımından kapalı, gerçek dünya ile fantastik dünyanın iç içe geçtiği, çok parçalı bir öykü olarak değerlendirilebilir. Parçalar içindeki anlam, sözcüklerin imge gücünden yararlanılarak oluşturulur. Gerçek ile hayalin çarpışmasıyla çağrışım zenginliği yaratılır. Bölünmüş, dağınık her bir parçanın toplamında imge değeri yüksek bir dil meydana gelir. Askeri darbe ya da militarizm eleştirisi bu imgelerle yapılır. Örneğin, iplere dizili çamaşırlar, devrilen kamyonlar, makinenin sesi, deri çizmeler, insan kemikleri (Soysal 2012: 21-22) bu eleştirinin simgesel gücü olarak görülebilir ve böyle bir anlatımın sinemadaki karşılığ 1 "metaforik kurgu" dur.

\section{3. "Akhisarlı"}

Necati Cumalı'nın bu öyküsünün izleği “kadın”dır. Günlük hayatta karşılaşılabilecek kadın sorunlarına değinen yazar, özellikle toplumdaki cinsel sorunları öyküsüne yansıtır. Ayrıca, ekonomik yapı ya da ataerkil düşünüş biçiminin vurgulandığ1 bu öykü, hareket ögeleriyle zenginleştirilmiştir. "Akhisarlı” başkarakterleri erkek olan bir anlatı olarak, erkeğin bakış açısının hâkim olduğu "kadın temalı" bir öykü formu olarak değerlendirilebilir. Buna göre öykünün film senaryosuna dönüştürülmüş şekli şöyle sıralanabilir:

1. İzmir-Ankara treninde üç kişi

2. Akhisarl1

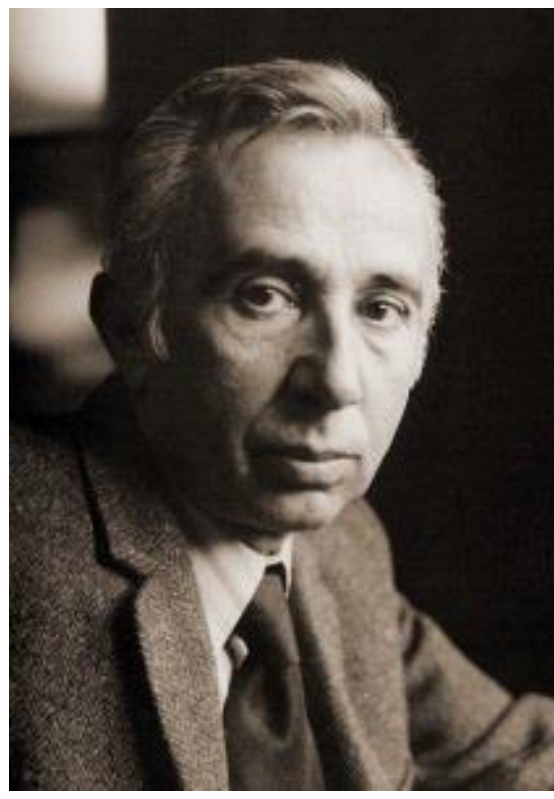

Necati Cumalı

3. Hoca ve Akhisarlı

4. Öğrenci ve Akhisarlı

5. Öğrenci, Akhisarlı ve Akşehirli Hoca

Öykü İzmir-Ankara treninden Afyon'a yolculuk yapan üç kişinin tanıtımıyla başlar: “Trenin üçüncü bölmesinin birinde, pencerenin iki yanında bir hoca ile bir üniversite 
öğrencisi, öğrencinin solunda ise bir er vardı" (Cumalı 2013: 144). Genel planda üçünün görüntüsü ön plana çıarılırken öyküde yer almayan bir anlatıcı tarafından bu kişiler hakkında bilgi verilir. Bu durumda Akşehirli Hoca, hukuk fakültesi öğrencisi ve Akhisarlı bir er, öyküde laboratuvar ortamının parçaları gibi düşünülebilir.

\section{1. İç Konuşmalar ve Karşı Açı Çekim}

$\mathrm{Bu}$ kısa bilginin ardından, kamera ikinci sahnede panoramik çekimle koridordan geçen kadınları, kızları gösterir. Ancak burada kamera görevi gören şey, Akhisarlı'nın gözleridir. Akhisarlı'nın iç konuşmaları ise anlatıcı aracılığıyla aktarılır. Erin kadınların arkasından koridora çıkışı, onlara bakışı, tren istasyonlarında pencereye fırlayıp dışarıda yolcuları karşılayan kadınları, kızları izleyişi genel planda çekilir. Yakın planda erin iç çekişi ve “Allahım, neler yaratmışsın! Bu can bu güzellere nasıl dayansın?” (Cumalı 2013: 144) sözlerine yer verilir.

Üçüncü sahnede, Hoca'nın ere ögü̈ü̈, karşı açı çekimde yansıtılır. Karşı açı çekim Monaco'nun da dile getirdiği gibi birbirleriyle konuşan kişilerin dönüşümlü gösterilmelerinde kullanılan ve izleyiciyi içine alan samimi bir havanın oluşmasını sağlayan çekimlerden biri olarak kabul edilir (2013: 203). Burada çatışma unsuru, karşılıklı konuşmalarda gizlidir. Konuşmada “Başkasının karısına kızına bakarken yüreğini bozma evlât" diyen Hoca'nın uyarısı üzerine erin "Elimde mi? Görmüyor musun o saçları, bacakları, o incecik belleri?" sözlerine yer verilir (Cumalı 2013: 144).

Öğrencinin bu konuşmaya gülüşü, Hoca'nın başını sallayışı panoramik çekimle gösterildikten sonra kamera Akhisarlı'ya yönelir. Dördüncü sahnede, onun ve öğrencinin karşı açı çekimde görüntüleri gösterilir ve hayatları hakkında bilgiler diyaloglar yardımıyla okura sunulur. Akhisarlı'nın evli olmadığı için öğrenciye dudak büküşü yakın planda çekilir. Anlatıcı bu çekimde araya girerek Akhisarlı'nın on altısında evlendiği bilgisini okurla paylaşır ve bu diyalogda karşı açı çekimle birlikte sağlı-sollu çekim (panoramik) kullanılır. Diyaloğun devamı ise şöyledir:

“Yavuklun, nişanlın yok mu?"

"Yok" diyebilirdi, ama salt onun ne diyeceğini anlamak için "Var!" dedi.

“Nasıl bari, mercimeği fırına verdiniz mi aranızda?"

Öğrenci oyununu sürdürdü:

"Acelemiz yok."

Akhisarlı'nın hiç aklı ermedi bu işe (Cumalı 2013: 145).

Bu diyaloğu Hoca'nın görüntüsü böler. Burada yine panoramik çekimden yararlanılır. Öykünün son sahnesi, kısa açıklamalar dışında karşılıklı konuşmalara dayandırılır ve anlatıcı aradan çekilir. Hoca'nın devreye girmesiyle birlikte kentli-köylü kavramları üzerine bir tartışma başlar. Öğrencinin evlilik konusundaki düşünceleri Hoca'ya göre “kentli 
düşüncesi"dir ve onun bu görüşü Akhisarlı tarafından da kabul görür. Kısa diyalog, grubun kısa süre susmasının genel çekimi ve Akhisarlı'nın yakın planda düşünceli tavrının gösterilmesiyle bozulur. Sessizliği bozan şey, Akhisarlı'nın öğrenciye "Kız erkek karışık mı okursunuz Ankara'da" sorusudur (Cumalı 2013: 146). Öğrencinin "Karışık" cevabıyla tild çekimde Akhisarlı'nın dizine indirdiği şaplak, yakın çekimde ise adamın iç çekişi gösterilir.

\subsection{Zum ve Geriye Sapma (Flashback)}

Anlatıcı sınırsız bilgiye sahip olduğu için Akhisarlı'nın iç dünyasını okura aktarmaktadır: "Sivilceli yüzlü, ufak tefek bir delikanlıydı. Ne öyle yakışıklı, ne güçlü kuvvetli. Nesine güveniyordu bu kadar kadınların önünde" (Cumalı 2013: 146). Burada öğrencinin sivilceli yüzü zumlanır. “Zum” Ryan'ın dikkat çektiği üzere bir objeye kesintisiz olarak yaklaşılması ya da yakındaki bir nesneden yine kesintisiz biçimde uzaklaşılmasıyla elde edilir (2012: 179). Devam eden karşı açı çekimde, öğrencinin Akhisarlı'ya “Evlisin. Şimdi de haftada bir karıştırıyor musun bir şeyler?" sorusu dikkat çeker. Bir sonraki bölümde, Akhisarlı'nın yakın planda parlayan gözlerinden Hoca'nın pencereden dışarıya bakarak mırıldanışının genel planına geçilir. Öğrenci ve Akhisarlı'ya kayan görüntüyle diyalog devam eder. Akhisarlı'nın ağzından karısının betimlemesi verilir ve bu bölümde zamanda geriye dönüş anlamina gelen flashback tekniği kullanılır:

Evlendiğimde, on beşinde ay parçası gibi bir kızdı benim karım. Ateş parçası gibiydi. Durduğu yerde duramaz, fıkır fıkır fıkırdardı. Ben işimi bilmez miyim? Baktım olacak gibi değil, üç yılda üç çocuk sardım başına. Şimdi biri eteklerinde, biri kucağında, biri beşikte. Kısacası gözünü yıldırdım, erkekten usandırdım karımı. İçinden geliyorsa başını kaldırıp baksın başka erkeklere (Cumalı 2013: 147).

Bu açıklamanın ardından Akhisarlı'nın yakın planda ellerini ovuşturması çekilir sonra da tekrar bir flashbackle komşusunun karısını anlatmasına yer verilir: “Karısı bir içim su. Baktım kadının gözü bütün gün pencerede, daha benim karı ikinciye gebe iken uydurdum komşunun karısı ile işi" (Cumalı 2013: 147). Bu konuşmadan sonra görüntü değişir. Önce öğrenci, sonra Hoca görüntülenir. Panoramik çekime elverişli bu görüntülerin ardından genel plana yer verilir. Genel planda Hoca'nın ve öğrencinin pencereden dışarıya bakmaları gösterilir. Dış mekânda, karanlık bir yeryüzü görüntüsünden Akhisarlı'nın karısının betimlemesine -Hoca'nın on sekizinde yaşamaktan usanan karısının görüntüsüne- geçilir. Kadının çocuklardan birini beşikte sallaması, birini kucağında hoplatması ile eteklerine asılan iki yaşındaki çocuk, peş peşe gösterilir. Bu görüntülerde sağl1-sollu hareketlere tild çekim de eklenir. Kadının genel planından sonra aşağı kayan görüntüde beşikte yatan bebek, yukarı kayan görüntüde kadının kucağındaki çocuk gösterilir. Tekrar aşağı kayan çekimde ise kadının eteğine yapışan başka bir çocuğun görüntüsüne yer verilir (Cumalı 2013: 148). 


\section{3. Çatışma Ögeleri ve Sahne Derinliği}

"Akhisarlı" aksiyon ögesinin baskın olduğu bir öykü olarak değerlendirilebilir. Öyküde çatışma unsurları diyaloglardan yararlanılarak oluşturulur. Öykü deneysel bir anlatı gibi düşünüldüğünde kahramanların çatışmayı desteklemek amacıyla yaratıldığı söylenebilir. Bir trende hukuk fakültesi öğrencisi bir gencin, Akhisarlı erin ve Hoca'nın toplumun belli kesimlerini temsil edecek şekilde yan yana getirildiği söylenebilir (Cumalı 2013: 148).

Film öyküsünün geçtiği alan (tren) tektir ve öykü kesintiye uğratılmadan aktarılır. Bu nedenle de öyküde "sahne derinliği"nin kullanıldığ 1 fark edilir. Ancak öyküdeki diyalogların bazısında flashback tekniği kullanılarak geçmişe gidilir, bu teknik Akhisarlı'nın ve komşusunun karısının anlatıldığı sahneler ile öykünün son sahnesinde öğrencinin Hoca'nın eşini hayal ettiği bölümde dikkat çeker (Cumalı 2013: 146-48). Fakat öykünün bütününde olay aktarılırken kesme yapılmaz, olaya müdahale edilmez.

\subsection{Anlatılan Çekim}

Daniel Arijon'a göre bir sahne çekiminde görüntü dışındaki herhangi bir nesne ya da olaydan söz edilebilir. Bu durumda, sözü edilen nesne ya da düşünce sahne içeriğine bağlı kalınarak kullanılır. Bu ana çekim içinde kurgulanan ara çekime "anlatılan çekim (cut away)" denilir (1993: 172). Öyküde de “kadın”ların ara çekim olarak kullanıldığ düşünülebilir. Öykü üç erkeğin konuşmalarıyla ilerler. Konuşmanın tamamının konusu "kadınlar"dır: Trendeki kadınlar, istasyondaki kadınlar öykünün bir parçasıyken Akhisarlı'nın karısı ile komşusunun karısı öykünün dışında bir görüntü olarak -sahne içeriğine bağlı kalınarak- gösterilir. Kadın, konuşmalarda (Hoca ve Akhisarlı) bir "nesne" gibi değerlendirilir. Ara çekimlerde de bu işleviyle kadın, tekrar ön plana çıkarılır. Örneğin, Akhisarlı tren koridorlarındaki kızlardan gözünü alamaz. Kadınlar bacakları, saçları, ince belleriyle okura tanıtılır. Çünkü Akhisarlı için kadın görüntüden ibarettir (Cumalı 2013: 144). Ayrıca Akhisarlı'nın karısı ve komşusunun karısı da böyle bir tutumla betimlenir: "Evlendiğimde on beşinde ay parçası gibi bir kızdı benim karım. Baktım olacak gibi değil, üç yılda üç çocuk sardım başına. Şimdi biri eteklerinde, biri kucağında, biri beşikte”. Komşu kunduracının ara çekiminde kadın "bir içim su"dur (Cumalı 2013: 147). Görüldüğü gibi "kadın" hem temel izlek hem de ara çekim olarak öyküde kullanılır.

\subsection{Düz Kurgu}

Öyküdeki olayın bölünmeden anlatılması genel kurgu tekniklerinden "düz kurgu” ya karşılık gelir. Öyküde bir çekimden diğerine hareketin ve nesnelerin birbirine uyumlu şekilde kurgulandığı sonucuna varılabilir. Bu nedenle alan ya da sahne derinliğinin böyle bir 
kurguda yer alabileceği söylenebilir. Düz kurguda amaç, film öyküsünü bölmemektir. Bu kurguda kamera, kendini göstermeyecek bir şekilde olayların gelişmesini sağlar. Düz kurgu sayesinde olaylarda devamlılık sağlanır, olaylar kesintisiz bir biçimde seyirciye gösterilir.

Bilindiği gibi alan derinliği filmdeki olayın bölünmeden anlatılmasıdır. Dolayısıyla bu çekim yasası düz kurgunun doğal bir tekniği şeklinde değerlendirilebilir. Sonuç olarak da düz kurgunun yer aldığı bir çekimin alan derinliğini zorunlu kıldığı düşünülebilir. "Akhisarlı"da olay neden-sonuç ilişkisine göre ilerler. Kadına farklı bakış açıları kesilmeden anlatılır. Diyaloglarda da kişiler ve olay arasına girilmeden kadın kavramı tartışılır. İlk başta üç kişi tanıtılır, sonraki bölümlerde bu kişilerin birbiriyle iletişimi aktarılır. Dördüncü bir göz görevi gören anlatıcı ise bu konuşmaların arasına nadiren girer (Cumalı 2013: 144-48). Böylece öykü kesintisiz bir biçimde anlatılır ve görsel akış içinde kırılmalar olmaz. Sinemada bu özellik "devamlılık" ilkesiyle ifade edilir.

\subsection{Tipleme Kuramı}

“Tipleme" kuramını geliştiren Eisenstein, oyuncu kadrosunu yalnızca oyuna uygun fizyolojik ve ifadesel özelliklere sahip oyuncuları seçer. Şöyle ki Potemkin Zırhlısı filmindeki cerrah rolü için kömür taşıyan bir adamı seçer. Ona göre oyuncu sahneye çıkar çıkmaz ayırt edilmelidir (Wollen 2014: 37-38). Öyküye dikkat edildiğinde kahramanların fiziksel özelliklerinden ziyade kişilik özelliklerinin dikkat çektiği görülür. Akhisarlı bir er, Hoca ya da bir hukuk fakültesi öğrencisi konumlarının gerektirdiği şekilde hareket eder ve öyküde toplumun “kadın”a bakış açısı farklı grupları temsil eden bu kişilikler üzerinden yansıtılır. Dolayısıyla böyle bir kahraman seçiminin rastlantıya dayanmadığı söylenebilir. Erken yaşta evlendirilen ve eğitimli olmayan, toplum dişına itilmiş bir er; bilinçli bir öğrenci; geleneksel düşünce tarzını yansıtan bir Hoca, öykünün temel izleğini destekleyecek biçimde bir araya getirilen kişilikler olarak değerlendirilebilir.

\section{Sonuç}

Sonuç olarak sinemanın biçimci diliyle ve bu dile özgü terminolojiyle öykü evrenine diyalektiğin yasaları ışı̆̆ında yeni bir yorum kazandırılmıştır. Eserin iç dinamiklerini irdelemeye yönelik çözümleme bölümünde, özgün sayılabilecek kavramlara yer verilmiş, yaklaşık bir asrın birikimine sahip sinemanın çekim teknikleriyle de metnin tahlili desteklenmiştir. Bu yorum, eğretilemeye dayalı ve biçimci bir sinema anlayışının, sözcüklerin dünyasında gösterilebileceğinin kanıtıdır. Ayrıca bu sayede biçimci edebiyat, yeni "uygulama olanakları"yla buluşturulmuş, metnin alışılmadık bir teknikle incelenmesi sağlanmıştır. Buna göre, "Pencere" de merkezde yer alan bir olay ile fantastik dünyadaki başka bir olay art arda verildiği için koşut kurgunun varlığı tespit edilmiş, ayrıca bir filmde 
çekim parçalarının çekiciliği doğrultusunda oluşturulan üsttitremsel kurgunun öyküde kullanıldığı düşünülmüştür. Aynı zamanda öyküde avangart sinema, dramatik çatışma, peripeti ve panoramik ve tild çekim belirlenmiştir. "Bir Şeydi Hiçliği Hiç Olup Yitti" adlı öyküde filmin simgesel yönünü temsil eden görüntüler aracılığıyla anlam kazanan metaforik kurgu, sözcüklerin imge değeriyle yaratılmış, Eisenstein'a ait çizemsel, oylumsal ve görselişitsel alanlardaki çatışma ile çarpıcı kurgu, renk-ses ögeleri dikkat çeken diğer teknikler olarak çözümlemeye katkı sağlamıştır. “Akhisarlı” öyküsünde ise Akşehirli Hoca, öğrenci ve Akhisarlı bir er laboratuvar ortamının parçaları gibi düşünülmüş, bu özelliği nedeniyle de tipleme kuramı belirlenmiştir. Sahne derinliği, ara çekim, karşı açı çekim, anlatılan çekim, zum gibi kamera çekim teknikleri dışında olayların kesintisiz bir biçimde aktarılması sonucu da düz kurgu dikkat çeken diğer teknikler olarak fark edilmiştir.

\section{Kaynaklar}

Abisel, Nilgün (1989), Sessiz Sinema, Ankara: A. Ü. BYYO Yayınları.

Arijon, Daniel (1993), Film Dilinin Grameri, (Çev. Yalçın Demir ve diğer), Eskişehir: Anadolu Üniversitesi Yayınları.

Asiltürk, Cengiz (2014), Sinemada Diyalektik Kurgu (Filmin Dili), İstanbul: Kalkedon Yayınları. Aslanyürek, Semih (2011), Senaryo Kuramı, İstanbul: Pan Yayıncılık.

Burak, Sevim (2014), Yanık Saraylar, İstanbul: Yapı Kredi Yayınları.

Cumalı, Necati (2013), Ay Büyürken Uyuyamam, İstanbul: Yeni Gün Haber Ajansı Basın ve Yayıncılık A. Ş.

Eisenstein, Sergei (1984), Film Duyumu, (Çev. Nijat Özön), İstanbul: Payel Yayınları.

Eisenstein, Sergei (1985), Film Biçimi, (Çev: Nijat Özön), İstanbul: Payel Yayınları.

Felski, Rita (2010), Edebiyat Ne İşe Yarar?, (Çev. Emine Ayhan), İstanbul: Metis Yayınları.

Güral, Ufuk (2013), Sinema Tarihi, İstanbul: Detay Yayıncılık.

Küçükerdoğan, Bülent (2010), Sinemada Kurgu ve Eisenstein, İstanbul: Hayalbaz Kitap.

Monaco, James (2013), Bir Film Nasıl Okunur: Sinema Dili, Tarihi ve Kuramı, (Çev. Ertan Yılmaz) 15. Baskı, İstanbul: Oğlak Yayınları.

Özön, Nihat (2008), Sinema Sanatına Giriş, İstanbul: Agora Kitaplı̆̆ı.

Ryan, Michael (2012), Eleştiriye Giriş: Edebiyat-Sinema-Kültür, ( Çev. Nijat Özön), Ankara: De Ki Basım Yayım Ltd.

Soysal, Sevgi (2012), Tutkulu Perçem, İstanbul: İletişim Yayınları.

Wollen, Peter (2014), Sinemada Göstergeler ve Anlam, (Çev. Zafer Aracagök, Bülent Doğan), İstanbul: Metis Yayınları. 